\title{
O ESTADO NOVO E A INTEGRAÇÃO DO SAMBA COMO EXPRESSÃO CULTURAL DA NACIONALIDADE
}

\author{
Carla Araújo Coelho
}

Resumo: Este trabalho tem como proposta investigar os impactos que o projeto ideológico do Estado Novo surtiu no samba urbano carioca contribuindo para a sua consolidação como um elemento proeminente da identidade nacional brasileira. A proposta insere-se no projeto História e Música: identidades, memórias, histórias e busca sondar as representações de nacionalismo construídas por compositores sambistas questionando o motivo para essa suposta tendência. Ainda, deverá refletir sobre a possível relação que se estabeleceu entre o samba e o Estado Novo, e como ela poderá ter contribuído para a consolidação do samba como expressão cultural da nacionalidade brasileira.

Palavras-chave: Estado Novo, samba, identidade nacional.

* Graduada em História pelo Instituto de Ciências Humanas da Universidade de Brasília (UnB). 


\title{
O ESTADO NOVO E A INTEGRAÇÃO DO SAMBA COMO EXPRESSÃO CULTURAL DA NACIONALIDADE
}

\author{
Carla Araújo Coelho
}

\section{O samba como objeto da história}

A primeira metade do século XX foi um momento de grandes transformações para o Brasil. Recém saído do regime monárquico, a nova Nação enfrentava grandes desafios sociais, econômicos e políticos. A abolição da escravidão, os numerosos contingentes de imigrantes, assim como o grande fluxo de pessoas atraídas pelo desenvolvimento industrial em direção aos centros urbanos, tornavam as cidades, pouco estruturadas, em grandes aglomerados desordenados. Por outro lado, o crescimento desses centros urbanos transformou as grandes cidades em ambientes verdadeiramente frutíferos para a sociabilidade e, não é demais lembrar, o desenvolvimento tecnológico já vinha surtindo impacto na indústria do entretenimento. ${ }^{1}$ Cada vez mais repleta de centros de diversões, tais como cafés-cantantes, cinemas e teatros, o Rio de Janeiro apresentava-se como um ambiente promissor para artistas e compositores.

${ }^{1}$ Cf. CUNHA, Fabiana Lopes da. Da marginalidade ao estrelato: o samba na construção da nacionalidade (1917-1945). São Paulo: Annablume, 2004. 
O samba encontrou nessa enriquecida realidade cultural um caminho para atingir os mais variados públicos. Sabe-se que o grupo "Oito Batutas"2 havia ganhado tanta notoriedade que em 1922 conseguiu patrocínio para ir a Paris divulgar sua música. A popularidade que o samba vinha alcançando tornou-o alvo de interesse do governo de Getúlio Vargas, tonando-o um instrumento complementar do projeto ideológico nacional. ${ }^{3}$

Não seria esta a primeira vez que um Estado autoritário se apropriaria da música como arma de propaganda de ideais políticos. A URSS, já percebendo a arte como fator de transformação política e social, estabeleceu diretrizes da arte de modo que ela passasse a cumprir a função de preservação da cultural popular e fosse capaz de refletir os anseios do "povo", sempre de acordo com a perspectiva do partido comunista. ${ }^{4} \mathrm{O}$ Estado Nazista Alemão também utilizaria a música como recurso para disciplinar, estimulando certas temáticas e censurando outras. O nazismo compreendia o caráter coletivista da música, e seu potencial de transformar a multidão numa "massa perturbadora". ${ }^{5}$ Dessa forma, durante os anos 20 e 30 , o sentido

${ }^{2}$ Grupo conhecido por tocar uma diversidade de gêneros musicais, em especial o samba. Donga, um de seus integrantes, foi o criador da música Pelo Telefone, considerada o primeiro samba registrado.

${ }^{3}$ CALDEIRA, Jorge. A construção do samba. São Paulo: Mameluco, 2007, p. 40.

${ }^{4}$ CONTIER, Arnaldo Daraya. “Arte e Estado: Música e poder na Alemanha dos anos 30". Revista Brasileira de História - São Paulo, ANPUH/Marco Zero. Vol. 8, $\mathrm{n}^{\circ} 15$, set./1987-fev./1988, p. 127.

${ }^{5}$ Idem, ibidem. 
coletivista da música acabou sendo absorvido pelos movimentos nacionalistas, e o caso do Estado Novo no Brasil não seria diferente.

Este estudo procurou compreender o porquê e como se deu essa relação entre o samba e o Estado Novo, assim como investigar os impactos que essa relação teria surtido no samba, culminando com a sua consolidação como símbolo nacional. Esses objetivos foram alcançados a partir da análise de um corpus documental composto de composições musicais da época, enredos vencedores de concursos entre escolas de samba, e artigos veiculados na revista Cultura Política, além do apoio de uma bibliografia especializada. A essas fontes foram lançados os seguintes questionamentos: como se deu a relação entre o Estado Novo e o samba? Por que foi estabelecida essa relação? Como esta relação contribui para a consolidação do status do samba como música-símbolo nacional? Quais as condições socioeconômicas, políticas e culturais que contribuíram no processo de consolidação do samba como símbolo nacional?

\section{História e música: diálogos}

O período do Estado Novo é freqüentemente associado com a ascensão do samba como gênero nacional e, conseqüentemente, como símbolo cultural da nacionalidade brasileira. No entanto, muito freqüentemente, em períodos pós-revolucionários, ou em tempos de ruptura com a ordem política - tal como o caso do Estado 
Novo - cria-se uma certa mística em torno das realizações, reais ou imaginárias ${ }^{6}$, do governo em questão.

Sabe-se que desde a proclamação da república em 1889, já vinha sendo realizado um esforço de parte dos intelectuais brasileiros em torno da definição de uma identidade nacional brasileira, e da delimitação de elementos tidos por tipicamente nacionais. E é nesse contexto que o samba vinha se tornando cada vez mais popular dentre os variados estratos sociais do Rio de Janeiro.

A problemática que guiou este trabalho foi justamente a questão de como o samba passaria a ser incorporado a esse conjunto de símbolos nacionais. Ou melhor, como o Estado Novo de Getúlio Vargas e seu projeto ideológico contribuíram para que essa associação fosse traçada. Quais teriam sido as condições conjunturais, materiais e simbólicas que transformariam o samba em símbolo nacional, processo que permitiu que o mesmo fosse utilizado pelo governo como um dos veículos de sua propaganda ideológica.

A escolha deste tema deu-se em grande parte pela constatação da existência de uma crescente produção historiográfica ${ }^{7}$, mas

${ }^{6}$ LAUERHASS, Ludwig Jr. Getúlio Vargas e o triunfo do nacionalismo brasileiro. São Paulo: Itatiaia/Edusp, 1986, p. 17.

${ }^{7}$ Tendo como exemplo desde os pioneiros Mario de Andrade e o crítico musical e historiador José Ramos Tinhorão até as produções mais recentes como as de José Miguel Wisnik e de Adalberto Paranhos. Cf. ANDRADE, Mario de. Ensaio sobre a música brasileira. São Paulo: Martins, 1962; TINHORÃO, José Ramos. Pequena história da música brasileira. São Paulo: Martins, 1962; WISNIK, José Miguel. O coro dos contrariados: a música em torno da Semana de 22. $2^{\text {a }}$ ed., São Paulo: 
também interdisciplinar, ${ }^{8}$ voltada ao estudo da música, várias delas focadas, inclusive, no período aqui delimitado. Esse crescente interesse sinaliza para a importância dos estudos que buscam compreender a música como uma "expressão cultural [que pode ser tomada] como objeto a ser explorado e importante fonte de acesso às tramas que buscam dar sentido à realidade estudada, esteja ela localizada no passado recente ou em tempos remotos."

Este trabalho se identifica com a abordagem da Nova História Cultural, dando ênfase à dimensão cultural da experiência humana e buscando compreender os elementos simbólicos compartilhados por um determinado grupo de um determinado recorte histórico. ${ }^{10}$ Neste caso, a compreensão almejada deverá ser mediada por elementos musicais, fazendo da música uma ponte com o passado, logo, uma fonte a ser analisada, além de objeto de estudo. O historiador Marcos

Duas Cidades, 1983; PARANHOS, Adalberto. Os desafinados: sambas e bambas no Estado Novo. 2005. Tese - Doutorado em História - Pontifícia Universidade Católica de São Paulo.

${ }^{8}$ Caso do próprio Adalberto Paranhos, que introduz em sua produção uma abordagem sociológica, e de José Miguel Wisnik, que não deixa de incorporar sua competência musical técnica a suas análises históricas.

9 BRITO, Eleonora Zicari Costa de. "História e música: tecendo memórias, compondo identidades". Textos de História. Revista de Pós-Graduação em História da Universidade de Brasília. Vol. 15, n¹/2, 2007, p. 209.

${ }^{10}$ Dentro da perspectiva de História Cultural de Roger Chartier. Do autor, ver, principalmente: CHARTIER, Roger. História Cultural : Entre Práticas e Representações. Rio de Janeiro/Lisboa: Difel / Bertrand, 1990. 
Napolitano descreve da seguinte maneira a operação a ser seguida pelo pesquisador em música popular:

[Deve-se] mapear as camadas de sentido embutidas numa obra musical, bem como suas formas de inserção na sociedade e na história, evitando, ao mesmo tempo, as simplificações e mecanismo analíticos que podem deturpar a relação polissêmica e complexa de qualquer documento de natureza estética. $^{11}$

\section{O samba no contexto do Estado Novo}

Em dezembro de 1939, Getúlio Vargas cria o Departamento de Imprensa e Propaganda - DIP. Funcionando como um aperfeiçoamento de um órgão já existente - o Departamento Nacional de Propaganda - o DIP teria como propósito a difusão da ideologia do Estado Novo junto às camadas populares. ${ }^{12}$ Este propósito seria atingido através do controle dos setores de divulgação: radiodifusão, teatro, cinema, turismo e imprensa. Cabia ao DIP promover produções artísticas que fossem do interesse do

${ }^{11}$ NAPOLITANO, Marcos. História \& música. Belo Horizonte: Autêntica, 2002, pp. 77-78.

${ }^{12}$ Informações encontradas em verbete sobre o Departamento de Imprensa e Propaganda do site do CPDOC, disponível em: http://cpdoc.fgv.br/producao/dossies/AEraVargas1/anos3745/EducacaoCulturaPropaganda/DIP, com acesso em 21/08/2013. 
Estado, censurar as que fossem de encontro a esses mesmos interesses, organizar manifestações cívicas e festas patrióticas, coordenar a propaganda nacional, controlar informações, entre outras diversas formas de controle da vida cultural de uma sociedade. Em seu livro O que é Propaganda Ideológica, Nelson Jahr Garcia define a propaganda ideológica como sendo um conjunto de mensagens, representantes de uma versão da realidade, cuja

...função é a de formar a maior parte das idéias e convicções dos indivíduos e, com isso, a orientar todo o seu comportamento social. Ass mensagens apresentam uma versão da realidade a partir da qual se propõe a necessidade de manter a sociedade nas condições em que se encontra ou de transformá-la em sua estrutura econômica, regime político ou sistema cultural. ${ }^{13}$

Essa propaganda pode assumir as mais diversas formas $\mathrm{e}$ utiliza-se dos mais variados recursos de divulgação, servindo não apenas para divulgar idéias, mas também para incutir visões de mundo e histórias, atribuir-se uma função social, assim como para impor valores e padrões de comportamentos tidos por adequados. $\mathrm{O}$ autor segue explicando que a realização da propaganda segue determinadas etapas. Primeiro tem-se a fase da elaboração, quando o grupo emissor deve adequar a mensagem à realidade que deverá absorvê-la. Em seguida vem a fase da codificação, que corresponde ao

${ }^{13}$ GARCIA, Nelson Jahr.O que é propaganda ideológica. São Paulo: Brasiliense. 1994, p. 10. (Coleção Primeiros Passos) 
momento em que as idéias a serem difundidas são transformadas em mensagens que atraia a atenção do receptor. Por último ocorre a difusão sistemática da mensagem. Este é o momento em que a mensagem é transferida ao receptor pretendido, destacando-se como mais apelativa a difusão oral. ${ }^{14}$

Essas reflexões parecem-me pertinentes e serão utilizadas para apreender a relação entre o samba, como gênero musical corrente e popular, e as iniciativas do Estado Novo para realização de seu projeto ideológico de unificação nacional. O controle exercido pelo DIP, o estímulo a compositores do samba para criarem músicas apologéticas ao governo e a seus valores, o papel da radiodifusão na divulgação de determinadas composições, assim como a promoção de concursos musicais deverá ser compreendida a partir da perspectiva de propaganda ideológica apresentada por Nelson Jahr Garcia. $^{15}$

Outro aspecto a ser destacado diz respeito à noção de identidade nacional, entendida como uma construção sociocultural, resultante de um processo de produção simbólica e discursiva ${ }^{16}$, que

\footnotetext{
${ }^{14}$ Idem, p 65.
}

15 A questão da recepção/apropriação dessas mensagens como um momento importante na própria produção de sentidos atribuídos a esses bens culturais não foi ignorado, mas, neste trabalho não foi possível um debruçar-se sobre essa dimensão da produção cultural.

${ }^{16}$ SILVA, Tomaz Tadeu da. "A produção social da identidade e da diferença" In: (Org.). Identidade e diferença: a perspectiva dos estudos culturais. 4. ed. Petrópolis: Editora Vozes, 2005, p 81. 
funciona, em grande parte, por meio do que Benedict Anderson chamou de "comunidades imaginadas"17 - definida por Tomaz Tadeu da Silva da seguinte forma:

Na medida em que não existe nenhuma 'comunidade natural' em torno da qual se possa reunir as pessoas que constituem um determinado agrupamento nacional, ela precisa ser inventada, imaginada. É necessário criar laços imaginários que permitam 'ligar' pessoas que, sem eles, seriam simplesmente indivíduos isolados, sem nenhum 'sentimento' de terem qualquer coisa em comum. ${ }^{18}$

Tal processo é atingido mediante uma série de estratégias representacionais que constroem nosso senso comum sobre a identidade nacional, como a criação de símbolos, o apelo a mitos fundadores, a imposição de línguas nacionais, entre outras. Essas estratégias devem ser compreendidas pela consideração de que "uma cultura nacional nunca foi um simples ponto de lealdade, união e identificação simbólica. Ela é também uma estrutura de poder...". ${ }^{19}$

Nesse sentido, o que este trabalho percebe é que o Governo de Getúlio Vargas, entre os anos de 1930 e 1945, comportou-se como um catalisador no processo de consolidação da identidade nacional

\footnotetext{
17 ANDERSON, Benedict. Imagined Comunities. Londres: Verso, 1983. Apud SILVA, op. cit., p. 85.

${ }^{18}$ SILVA, op. cit., p. 85.

${ }^{19}$ HALL, Stuart. Identidades Culturais na Pós-modernidade. Rio de Janeiro: DP\&A, 1997, p. 59.
} 
brasileira. Seus mecanismos de intervenção eram variados e tiveram um impacto transformador sobre a sociedade justamente por penetrarem profundamente no mundo das interações sociais, levando o Estado a aproximar-se das experiências cotidianas da população. E a música foi um desses veículos.

\section{Diálogos teórico-metodológicos}

Mas que música era essa? Tratava-se do que se conhece como música popular. A categoria popular, segundo Marcos Napolitano ${ }^{20}$, quando atribuída à musica, poderá assumir uma dessas quatro definições apresentadas por esse historiador: ${ }^{21}$

1) Definições Normativas: música "popular" como inferior.

2) Definições Negativas: música popular definida por aquilo que ela não é.

3) Definições Sociológicas: nesta linha a música popular estaria associada a (ou produzida por) grupos sociais específicos.

4) Definições tecnológicas/econômicas: música popular como produto exclusivo dos mass media, disseminada no grande mercado.

\footnotetext{
${ }^{20}$ NAPOLITANO, Marcos. História e Música: história cultural da música popular. 3. ed., Belo Horizonte: Autêntica, 2005.

${ }^{21}$ Idem, p. 14.
} 
Neste momento, a linha conceitual de que se valerá este trabalho atinge um impasse. As primeiras duas definições são descartadas prontamente por não se adequarem ao que se compreende como samba, da perspectiva de um gênero musical. Já as duas seguintes, são tão adequadas quanto inapropriadas à linha de pesquisa que venho propondo.

A definição sociológica pressupõe a atribuição das composições e do desenvolvimento do samba como algo restrito a uma classe social definida. Essa visão é muito difundida no senso comum, aonde o samba é freqüentemente associado como proveniente do "morro", ou seja, algo cultivado pelas camadas mais baixas. A própria palavra "samba" designava as festas de dança dos negros escravos, sobretudo da Bahia do século XIX. ${ }^{22}$ No entanto, após essa primeira geração, chamada por alguns de autêntica, o samba passou a ser compartilhado por diversos estratos das camadas sociais urbanas, tanto no sentido de apreciação quanto no de produção. Hermano Vianna apresenta essa relação interclasse como um dos mistérios do samba em seu livro homônimo. ${ }^{23}$ Isso ocorria não apenas em nível nacional quanto no nível internacional, constituindo o fenômeno conhecido como transculturação. ${ }^{24}$ Dessa

\footnotetext{
${ }^{22}$ Idem, p. 51.

${ }^{23}$ VIANNA, Hermano. O mistério do samba. 5. ed. Rio de Janeiro: J Zahar, 2004.

${ }^{24}$ Definida, por Bronislaw Malinowski, como "um processo no qual sempre se dá algo em troca do que se recebe; é um "tomar e dar"... É um processo no qual ambas as partes da equação resultam modificadas. Um processo do qual resulta uma nova
} 
forma, para manter um rigor conceitual, esta definição não poderá ser seguida estritamente, mas deverá ser lembrada uma vez que corresponde à imagem que o samba assumiu, ao longo dos anos, no imaginário coletivo.

Quanto à quarta definição, tecnológico-econômica, esta corresponde à analise que associa o samba à radiodifusão, uma vez que o recorte temporal escolhido é conhecido justamente como a "era de ouro do radio". A radiodifusão foi um dos principais recursos de difusão da ideologia política do Estado Novo. O samba, como gênero musical de grande apelo, não deixaria de se beneficiar desse novo recurso de difusão. No entanto, não se pode esquecer que o samba tem como uma de suas formas de desenvolvimento e reprodução o meio social propriamente dito, sem mídias intermediárias. ${ }^{25}$

realidade, composta e complexa. Uma realidade que não é uma aglomeração mecânica de características, nem sequer um mosaico, mas um fenômeno novo, original e independente." Em introdução feita à publicação do antropólogo Fernando Ortiz, cf. ORTIZ, Fernando. Contrapuento cubano Del tabaco y el azucar. Caracas: Bibl Ayacucho, s/d.

${ }^{25}$ Como no caso do chamado samba de partido-alto: "O que hoje se conhece como partido-alto é uma modalidade de cantoria. E cantoria é a arte de criar versos, em geral de improviso, e cantá-los sobre uma linha melódica pré-existente ou também improvisada (...). Improvisação repentina, cantada à moda de "peleja", numa espécie de duelo verbal, como outras modalidades de cantoria, o partido-alto tem a distinguí-lo a circunstância de que se realiza e completa na roda de samba, sempre 


\section{O samba, o rádio e o Estado Novo}

Durante os anos da ditadura do Estado Novo, práticas nacionalistas e autoritárias passaram a agir de forma complementar no processo de formação do Estado Nacional, expandindo as pretensões de atuação do novo regime totalitário de forma a abarcar a totalidade das manifestações da vida nacional, ${ }^{26}$ pelo menos do ponto de vista das políticas de Estado. Contando com um projeto político-ideológico muito bem articulado, o Estado tomaria para si a responsabilidade de se ocupar de cada cidadão, formando sua consciência individual e coletiva através da propaganda e da educação cuja conseqüência deveria ser a edificação da Nação e de seus cidadãos a uma suposta unidade orgânica. ${ }^{27}$ Nesses termos, compreendia-se que Estado político e a nação cultural deveriam coincidir. Para tanto, seriam criados aparatos culturais, próprios do Estado, destinados a produzir e difundir suas concepções de mundo para o conjunto da sociedade. ${ }^{28}$

Essa dimensão do projeto político estado-novista é evidenciada claramente na revista oficial do DIP, Cultura Política. Dirigida por Almir de Andrade, a revista circulou entre 1941 e 1945

de forma bem humorada e brincalhona”. XANGÔ. Xangô da Mangueira: recordações de um velho batuqueiro. Rio de Janeiro: Casa, 2005, p. 29.

${ }^{26}$ OLIVEIRA, Lúcia Lippi; VELLOSO, Mônica Pimenta; GOMES, Angela Maria de Castro. Estado Novo: ideologia poder. Rio Janeiro: Zahar Ed., 1982, p. 19.

${ }^{27}$ Idem, p 71.

${ }^{28}$ Idem, p 72. 
com a proposta de "definir" e "esclarecer" os rumos das transformações político-sociais do país a partir de estudos brasileiros. ${ }^{29} \mathrm{~A}$ intenção do Estado Novo de buscar envolver os variados setores sociais na política do Estado, entre esses setores o artístico, é declarada e assume forma de discurso veiculado na imprensa escrita por meio dessa revista. Logo em sua primeira edição, argumenta-se que "as artes andam passo a passo com o exercício deste ou daquele regime", seguida da afirmação de que "há um real e palpável progresso artístico no país" que seria uma 'verificação ostensiva' da primeira afirmação. Essa linha de pensamento é evidenciada durante todo o período de circulação da revista, na sessão "Brasil social, intelectual e artístico".

É nesse momento que o samba e o Estado Novo se cruzam. Sendo todas as manifestações artísticas nacionais a equivalência da nova política do Brasil, nos planos estéticos ${ }^{30}$, a crescente popularização do samba e seu respaldo dentre as camadas populares urbanas fez dessa ligação algo quase que inevitável.

Para se compreender o florescimento do samba como gênero nacional reconhecido como parte da identidade nacional, tanto a partir da ação consciente dos agentes envolvidos em ambos os lados (Estado e artistas) quanto a partir da consideração de questões conjunturais, algo que deve ser destacado é o desenvolvimento da

\footnotetext{
${ }^{29}$ Idem, p 76.

${ }^{30}$ Cultura Política - Revista Mensal de Estudos Brasileiros. Vol. 1, n. 1; mar. 1941, p. 282.
} 
indústria radiofônica no Brasil. O radio apareceu no Brasil em 1923, com a fundação da Radio Sociedade do Brasil. ${ }^{31}$ Daí em diante o radio passou a ser um importante mecanismo de circulação do samba, que viria a contribuir de forma importante na sua popularização.

O rápido aprimoramento dos mecanismos de circulação musical através do desenvolvimento interno da indústria fonográfica e radiofônica fez com que o samba deixasse de ser mero valor de uso transformando-se também em valor de troca. ${ }^{32}$ Essa transformação gerou uma crescente preocupação com a questão da autoria musical e também resultou na profissionalização de um grupo de compositores. ${ }^{33}$ Este novo grupo de artistas aprenderia a se adaptar às novas exigências impostas por esse contorno mercadológico que a produção musical assumira. Muitos compositores passam a dar preferência a um discurso lírico-amoroso, tendo como principal tema a Mulher e o Amor. A historiadora Claudia Matos associa essa opção feita por alguns compositores à tentativa de atingir um público mais heterogêneo e superar o obstáculo da fronteira de classes na comercialização do samba. ${ }^{34}$ Nesse aspecto, pode-se inclusive dizer

\footnotetext{
${ }^{31}$ CALDEIRA, Jorge. A construção do samba. São Paulo: Mameluco, 2007, p. 34.

${ }^{32}$ MATOS, Claudia. Acertei no milhar: samba e malandragem no tempo de Getúlio. Rio de Janeiro: Paz Terra, 1982, p. 19.

${ }^{33}$ Segundo Claudia Matos, houve uma série de compositores que resistiram a esse processo de profissionalização mantendo-se presos às raízes folclóricas do samba. ${ }^{34}$ Idem, p. 46.
} 
que o samba estaria cumprindo seu papel como símbolo cultural nacional costurando as diferenças numa única identidade. ${ }^{35}$

$\mathrm{O}$ potencial da indústria radiofônica, como meio de comunicação caracterizado pela facilidade de penetração e rapidez de divulgação de idéias, foi também percebido e usufruído pelo Estado. $O$ radio passaria a ser considerado um instrumento em prol do "engrandecimento e da prosperidade da Nação". ${ }^{36}$ Essa relevância do rádio como veículo de difusão do discurso do Estado, não se esgotava na eficiência de sua transmissão de mensagens, sendo reforçada também pelo seu potencial de atingir uma vasta gama de pessoas das mais variadas regiões do país, assegurando a base de sustentação policlassista do Estado Novo. ${ }^{37}$ No que concerne à arte, mais especificamente à música, o radio 'divulga as realizações de nossa arte, reverencia as nossas mais sagradas tradições e enaltece a vida e a obra de nossos grandes homens, mostrando enfim "o Brasil aos Brasileiros" ${ }^{38}$ possibilitando, segundo o plano do Estado Novo, o intercambio e a aproximação constante entre todos os brasileiros.

Em 1932 é lançado um decreto-lei ${ }^{39}$ que autoriza a veiculação da propaganda paga. Este decreto surtiria efeito na programação do

\footnotetext{
${ }^{35}$ HALL, op. cit., p. 65.

${ }^{36}$ Cultura Política, p 289.

${ }^{37}$ OLIVEIRA, Lúcia Lippi; VELlOSO, Mônica Pimenta; GOMES, Ângela Maria de Castro. Estado Novo: ideologia poder. Rio Janeiro: Zahar Ed., 1982, p. 72.

${ }^{38}$ Cultura Política, p. 289.

${ }^{39}$ Decreto-lei 21.111.
} 
rádio, que assumindo um caráter mais voltado para a diversão, passaria a abrir as portas para a música popular em busca de atrair o máximo de ouvintes. ${ }^{40}$ No entanto, o samba, pelo espaço social onde majoritariamente se desenvolvia, abrigava em si um elemento de resistência. Ao deixar clara a situação existente de exclusão social, o samba, como musica popular, é entendido como um elemento de crítica. ${ }^{41}$

Em março deste mesmo ano lançou-se um decreto que reconhecia que o "serviço de radiodifusão é considerado de interesse nacional e de finalidade educacional". ${ }^{42}$ Dessa forma, ia aumentando a preocupação com o conteúdo das músicas tocadas, e conseqüentemente a censura a estas. Além de censurar composições cujas temáticas eram tidas como subversivas, os artistas eram atraídos a se engajar no programa ideológico do Estado Novo pelos cachês compensadores distribuídos pelo DIP. ${ }^{43}$

No momento em questão, esse potencial de ameaça apresentado pelo samba era percebido nas composições que

\footnotetext{
${ }^{40}$ CALDEIRA, Jorge. A construção do samba. São Paulo: Mameluco, 2007, p. 35.

${ }^{41}$ Idem, p. 19.

${ }^{42}$ Cultura Política, p 297.

43" Há boas razões para supor que o engajamento de vários sambistas no programa ideológico do Estado Novo não tenha resultado simplesmente de uma efetiva adesão ética e política, mas também, em muitos casos, de uma atitude oportunista e artificiosa. Abriam-se novos canais de divulgação para os compositores populares, e os cachês do DIP eram compensadores". MATOS, Claudia. Acertei no milhar: samba e malandragem no tempo de Getúlio. Rio de Janeiro: Paz Terra, 1982, p. 91.
} 
vangloriavam o ócio, a malandragem, e a vadiagem - temas que exaltavam o não-trabalho e iam de encontro à ideologia trabalhista de Vargas. ${ }^{44} \mathrm{O}$ recorrente tema da malandragem, que permeava as composições de sambistas da época foi cedendo lugar a composições apologéticas ao trabalho e à família - temas valorizados do governo varguista. Isso acontecia não somente por uma adesão política, mas também por uma atitude oportunista.

É nessa lógica que se deve entender como um sambista como Wilson Batista, que um dia declamara seu orgulho de ser tão vadio, na música Lenço no pescoço de 1933 - meu chapéu do lado / tamanco arrastado / lenço no pescoço / uma navalha no bolso /eu passo gingando provoco desafio / eu tenho orgulho de ser tão vadio / sei que eles falam deste meu proceder / eu vejo quem trabalha andar no misere / eu sou vadio porque tive inclinação / no meu tempo de criança tirava samba-canção - passaria a exaltar o trabalho em sambas como O Bonde São Januário, de 1940:

Quem trabalha é quem tem razão Eu digo e não tenho medo de errar O bonde São Januário Leva mais um operário Sou eu que vou trabalha

${ }^{44}$ PARANHOS, Adalberto. Entre sambas e bambas: vozes destoantes no "Estado Novo". Locus. (Juiz de Fora), v. 13, 2007. p. 180. 
Antigamente eu não tinha juízo Mas hoje resolvi garantir meu futuro

Vejam vocês

Sou feliz vivo muito bem A boemia não dá camisa a ninguém E, digo bem!

Claudia Matos se refere a essa nova tendência de temática que se contrapunha ao samba malandro como o "samba do malandro regenerado". Entre o amplo conjunto de composições musicais da época que seguem esta tendência, pode-se citar o samba Vadiagem, composto em 1929 por Francisco Alves:

A vadiagem eu deixei não quero mais saber arranjei outra vida porque deste modo não se pode viver

Eu deixei a vadiagem para ser trabalhador os malandros de hoje em dia não se pode dar valor.

Não se deve entender a partir disso que a relação entre Estado e músicos se deu assim de forma harmoniosa, com uma passiva submissão destes diante daquele. Autores como Adalberto Paranhos e, a acima citada, Claudia Matos se dedicaram exclusivamente ao estudo de segmento de compositores que não apenas não se adequaram aos parâmetros estabelecidos pelo Estado Novo, como 
contestaram de maneira mais ou menos sutil através de composições muitas vezes com conotações dúbias - o chamado "coro de vozes destoantes." 45 No entanto, não convém a esse trabalho analisar o espaço de disputa entre estes artistas e o Estado Novo, mas sim, usar essa ocorrência para enfatizar a estreita ligação entre o Estado e o samba, com um reconhecimento mútuo um do outro.

Outra tendência temática e estilística na produção do samba que surgiu, direta ou indiretamente, sob influencia do Estado Novo, foi o samba apologético-nacionalista, conhecido como sambaexaltação. Mais conhecido através da obra de Ary Barroso de 1939, Aquarela do Brasil, este estilo é caracterizado por seu discurso nacionalista e ufanista, bem retratado nos seguintes trechos da canção:

Brasil

Meu Brasil brasileiro

Mulato inzoneiro

Vou cantar-te nos meus versos

Brasil, samba que dá

Bamboleio, que faz gingá

O Brasil do meu amor

Terra do Nosso Senhor

... Esse Brasil lindo e trigueiro

É o meu Brasil brasileiro

Terra de samba e pandeiro...

\footnotetext{
45 A esse respeito, ver: PARANHOS, "Entre sambas e bambas"; Os desafinados. Sambas e bambas no "Estado Novo". Tese (Doutoramento em História), PUC- SP, 2005.
} 
Passa-se então a dedicar sambas inteiros à exaltação do Brasil, terra de nosso senhor, e os atributos que ilustram sua grandeza. Essa tendência pode ser percebida também nos versos de Francisco Alves de 1940: "Onde o céu e mais azul / ai se encontra o meu pais / o meu Brasil, grande... tão feliz" ${ }^{46}$ Mais uma vez vemos o samba cumprindo a função de símbolo cultural nacional ao suprimir contradições internas e "meter no mesmo saco toda a variedade de brasis que existem." ${ }^{47}$

Lembrando do conceito de Benedict Anderson de 'comunidade imaginária', a partir da qual são originadas as nações e conseqüentemente as identidades nacionais, ao transmitir para o ouvinte a idéia de brasilidade que permeia sua composição característica, o samba-exaltação cumpria a função de ligar as pessoas em torno da comunidade imaginária que seria o Brasil, ao exaltar seus atributos. Este gênero de samba contribui para a construção da representação do que é a identidade brasileira, e associará o samba cada vez mais estreitamente àquilo que é percebido como identidade nacional.

As mudanças sofridas pelo samba facilitaram a apreciação do mesmo como ritmo nacional e não regional ao desapropriá-lo de seu meio social de origem. Os novos eixos temáticos, seja o líricoamoroso ou o nacionalista, tornavam a música mais passível de ser

\footnotetext{
46 “Onde o céu é mais azul". Francisco Alves, J de Barro, A. Ribeiro e A. P. Vermelho, 1940.

${ }^{47}$ MATOS, op. cit., p. 48.
} 
assimilada por um extenso e heterogêneo grupo de ouvintes. Esse seria outro fator que contribuía para a opção pelo samba como gênero musical oficial do país considerando a forte preocupação do Estado em afirmar o caráter unitário do regime. ${ }^{48} \mathrm{O}$ samba, considerado arte nacional popularesca, com a nova preocupação que passava a demonstrar pelo Brasil em suas composições, contribuía para a corroboração da afirmação da revista Cultura Política que dizia que "do regionalismo, inconseqüente, dos primeiros momentos, passamos ao sadio nacionalismo artístico de agora". ${ }^{49}$

A transmissão obrigatória, a partir de 1938, do programa de rádio oficial do governo, Hora do Brasil, foi mais um elemento na engrenagem de auto-promoção da máquina propagandística montada pelo Estado Novo. ${ }^{50} \mathrm{O}$ programa seria transmitido obrigatoriamente em todas as emissoras do país entre as 7 e 8 da

${ }^{48}$ A cerimônia da queima das bandeiras, ocorrida pouco depois de declarado o Estado Novo - Getúlio Vargas incinerou as bandeiras dos estados brasileiros declarando a existência de uma só bandeira nacional - foi um ato simbólico representativo desse enfraquecimento do poder regional e estadual em nome da unificação da nação sobre a égide do Estado. GEORGE OLIVEN, Ruben. "O Nacional e o Regional na Construção da Identidade Brasileira”. Revista Brasileira de Ciências Sociais. Vol. 2. Anpocs. Disponível em http://www.anpocs.org.br/portal/publicacoes/rbcs_00_02/rbcs02_07.htm, acesso em 21/08/2013.

${ }^{49}$ Cultura Política, p. 281.

${ }^{50}$ PARANHOS, Adalberto. O Roubo da fala. Origens do trabalhismo no Brasil. São Paulo: Boitempo Editorial. 1ª Ed. 1999, p. 135. 
noite. Dentre o leque de atrações oferecidas pelo programa encontravam-se números musicais de artistas da música popular brasileira, aos quais era destinada a última meia hora. ${ }^{51}$ Pode se deduzir que o acesso a este espaço de divulgação nacional contribuirá para que o samba atingisse um público mais vasto, aproximando o samba urbano carioca das demais regiões do Brasil. Nesse aspecto é valido também nos lembramos da posição geográfica privilegiada que o samba ocupa como fator que também contribuiria para a sua identificação como gênero nacional. Segundo Adalberto Paranhos, em 1940, o Rio de Janeiro era a sede das três gravadoras existentes no país na época, ${ }^{52}$ favorecendo a ampliação do seu mercado consumidor e ampliando também o seu espaço no palco sócio cultural brasileiro. ${ }^{53}$ Sendo o Rio de Janeiro o lugar do samba, não seria insensato propor que o samba teria sido beneficiário, em certo nível, de um determinismo geográfico.

A promoção de concursos de música foi outra forma que o governo encontrara para influir no universo artístico nacional, ora oferecendo premiações a composições que apresentassem temáticas que corroboravam com o projeto ideológico nacional - valorização do trabalho, da família etc. - ora censurando as consideradas

\footnotetext{
${ }^{51}$ Idem. p. 136.

${ }^{52}$ PARANHOS, Adalberto. "A música popular e a dança dos sentidos: distintas face do mesmo". ArtCultura. Uberlandia-MG, n. 10, jul-dez., p. 24.

${ }^{53}$ MATOS, op. cit., p. 88.
} 
incompatíveis ao mesmo. ${ }^{54} \mathrm{O}$ mesmo aconteceria com os desfiles de Carnaval. Estes passariam a ser realizados, a partir de 1932, sob o auspício do Estado, na forma de competição. Já em 1937, as Escolas passariam a ser obrigadas, por decreto lei, a trabalhar com temas de caráter histórico, didático e patriótico. ${ }^{55}$ Sobre este atento olhar controlador do Estado, a Escola de samba Vizinha Faladeira, vencedora do concurso de $1937,{ }^{56}$ seria desclassificada, no concurso seguinte, por não apresentar um tema considerado de cunho nacionalista: A Branca de Neve e os sete anões. Entre as Escolas de samba premiadas durante a duração do Estado Novo, pode-se destacar a Portela por seu bom desempenho, sendo vencedora por cinco anos consecutivos (1941-1945). Entre os temas que foram apresentados em seu enredo está o "Brasil glorioso" - vencedor do concurso de 1944, e "Motivos patrióticos" - vencedor de 1945. ${ }^{57}$

Apesar de o processo de reconhecimento do samba como símbolo da identidade nacional brasileira ter se desenvolvido de forma interna, não se pode deixar de reconhecer a contribuição do

${ }^{54}$ FERREIRA, Jorge Luiz. "A cultura política dos trabalhadores no primeiro governo Vargas". Estudos Históricos. Rio de Janeiro, vol. 3, n. 6, 1990, pp. 180195.

${ }^{55}$ CALDEIRA, Jorge. A construção do samba. São Paulo: Mameluco, 2007, p. 100.

${ }^{56}$ A Escola venceu com o tema "Uma só bandeira", em homenagem à bandeira nacional e às bandeiras dos estados.

${ }^{57}$ Essas informações foram obtidas através do Dicionário Cravo Albin da Música Popular Brasileira, disponível em http://www.dicionariompb.com.br/escolas-desamba---as-campeas-atraves-dos-anos/dados-artisticos, acesso em 21/08/2013. 
elemento estrangeiro à atribuição ao samba do status de música oficial do Brasil. Em 1941, acompanhando uma visita da missão política da boa vizinhança do departamento de Estado dos Estados Unidos ao Brasil, Walt Disney entra em contato com a composição de Ary Barroso Aquarela do Brasil. Essa passa a ser então a musica escolhida para ser a trilha sonora do curta-metragem Saludos Amigos, produzido pelos estúdios da Disney, que buscava retratar, através de animação construída a partir de impressões registradas pelo mesmo durante sua visita aos países da America do Sul, uma relação amigável entre os países visitados e os Estados Unidos. ${ }^{58}$ Neste vídeo Zeca Carioca, personagem criado para representar o Brasil, amigavelmente se habilita a mostrar ao Pato Donald o 'país do samba', firmando, internacionalmente, a identificação do samba com o Brasil e vice e versa. ${ }^{59}$

${ }^{58}$ A animação 'Saludos Amigos” foi lançado não apenas dos Estados Unidos mas também em outros 19 países. Informação obtida no IMDb (Internet Movie Database), disponível em http://www.imdb.com/title/tt0036326/, acesso em $21 / 08 / 2013$.

${ }^{59}$ Prática inúmeras vezes repetida em diferentes momentos da história brasileira, o samba, sempre que preciso, irrompe na cena para mostrar o que é ser brasileiro, e muitas vezes a pedido dos próprios ilustres visitantes estrangeiros. Um exemplo entre muitos outros possíveis: "Em 1959 o Rio de Janeiro recebeu a visita da Duquesa de Kent, membro da família real britânica em passagem oficial pelo Brasil. Aconselhada pelo corpo diplomático a cumprir um roteiro cultural composto por apresentações de operetas e orquestras sinfônicas na capital, a visitante preferiu confrontar-se com o novo e solicitou conhecer de perto uma genuína escola de samba brasileira. O pedido causou uma desconcertante surpresa da chancelaria 
Quando se abordando a relação entre identidade nacional brasileira e a política da boa vizinhança norte-americana, é indispensável fazer menção à atriz-cantora Carmem Miranda, que passaria a ser considerada um dos maiores sucessos do projeto. Após seu sucesso na produção nacional de 1939, "Banana da Terra', onde popularizou a música "O que é que a baiana tem" ${ }^{60}$, a Embaixatriz do Samba ${ }^{61}$ seria protagonista de uma série de filmes norte-americanos, se transformando em um verdadeiro ícone de Hollywood. Em filmes como Serenata Tropical (1940) e Uma Noite no Rio (1941), a Pequena Notável ${ }^{62}$ exportaria ao exterior a imagem da identidade

anfitriã que se apressou em contatar a escola de samba Portela, solicitando que a agremiação fizesse um legítimo show de samba para a duquesa e representasse, sobre sapatos e ternos brancos, passistas, agogôs e repiniques, a autêntica cultura brasileira." PEREIRA, Cristiane dos Santos. Coisas do meu Pessoal. Samba e enredos de raça e gênero na trajetória de Leci Brandão. Dissertação de Mestrado em História Cultural. Universidade de Brasília, 2010, p. 66. Sobre o mesmo episódio, ver, também: CORD, Aline Mirilli Mac. "Deu samba nas relações internacionais II: dos anos dourados à globalização" Boletim da Associação dos Diplomatas Brasileiros. No ritmo da diplomacia - da crítica à invasão cultural americana à globalização, samba está presente nas relações internacionais. Ano XIII - No 56 - Janeiro / Fevereiro /Março 2007, pp. 17-19; SAUTCHUK, João Miguel. Brasil, Ritmos e harmonias: samba e identidades na música popular brasileira (segunda metade do século XX/ tempo presente). Trabalho de conclusão de curso. (graduação em História) - Universidade de Brasília, 2003.

60 “O que é que a baiana tem”, Dorival Caymmi, 1938.

${ }^{61}$ Com seria conhecida após seu êxito no exterior.

${ }^{62}$ Outra forma como era reconhecida. 
brasileira. A atriz-cantora contribuiria tanto na construção quanto na difusão da identidade brasileira no exterior,tanto através dos sambas que cantava quando através de sua própria imagem caracterizada por uma indumentária que congregava vários elementos do Brasil (ex: o traje da baiana ${ }^{63}$.

Percebe-se a partir desse projeto que houve um esforço sistemático realizado pelo Estado Novo em direção à edificação do nacionalismo brasileiro, tomando o samba como um de seus índices identitários, promovendo-o e ajudando na sua expansão tanto nacional quanto internacional.

O processo de elevação do samba a símbolo da identidade nacional contaria com a atuação consciente tanto de agentes do Estado quanto dos agentes sociais envolvidos na produção musical do samba. Os primeiros utilizariam o samba para expandir sua influencia sobre a dimensão social e cultural, ampliando as possibilidades do exercício do seu comando, para propagandear o regime e forjar um sentimento de união nacional patriótica. Já os segundos, desfrutavam do aumento dos canais de divulgação e, conseqüentemente, de uma expansão de sua esfera de influencia através da ampliação de seu alcance no território nacional.

A partir das questões levantadas por este trabalho pode-se inferir sobre a forte presença do Estado Novo no circuito do samba e como o período foi decisivo para a inclusão do mesmo no grupo de

${ }^{63}$ Para mais informações sobre Carmem Miranda, ver CASTRO, Ruy. Carmem, Uma Biografia. São Paulo: Companhia das Letras, 2005. 
símbolos da nacionalidade brasileira, sem contudo se querer afirmar que teria sido determinante. Um mosaico de outros fatores pontuais, como o desenvolvimento da indústria fonografia e o aumento da circulação industrial de produtos culturais também contribuíram para a compreensão do porquê o período ter sido tão marcante na trajetória sócio-cultural do samba. Desde então, o samba integrou-se de forma definitiva à identidade nacional a ponto de ser tombado pelo IPHAN ${ }^{64}$ como Patrimônio Cultural e Imaterial do Brasil, e em seguida, ser cunhado como Patrimônio Histórico Imaterial da Humanidade pela Unesco, em 2005; e hoje em dia, para não gostar de samba, só mesmo sendo ruim da cabeça ou doente do pé.

\section{Bibliografia}

ALENCAR, Edigar de. Nosso Sinhô do samba. Rio de Janeiro: Civilização Brasileira, 1968.

BRITO, Eleonora Zicari Costa. "História e música: tecendo memórias, compondo identidades". Textos de História. Revista da Pós-Graduação em História da UnB. Vol. 15, n. $1 / 2,2007$.

CHALHOUB, Sidney. Trabalho, lar e botequim. Campinas: Editora da Unicamp, 2001.

\footnotetext{
${ }^{64}$ Instituto do Patrimônio Histórico e Artístico Nacional.
} 
CHARTIER, Roger. História Cultural : Entre Práticas e Representações. Rio de Janeiro/Lisboa: Difel/Bertrand. Brasil, 1990.

CALDEIRA, Jorge. A construção do samba. São Paulo: Mameluco, 2007.

CORD, Aline Mirilli Mac. "Deu samba nas relações internacionais II: dos anos dourados à globalização" Boletim da Associação dos Diplomatas Brasileiros. No ritmo da diplomacia - da crítica à invasão cultural americana à globalização, samba está presente nas relações internacionais. Ano XIII - No 56 Janeiro / Fevereiro / Março 2007, pp. 17-19.

FENERICK, José Adriano. Nem do morro nem da cidade - as transformações do samba e a indústria cultural (1920-1945). São Paulo: Annablume Editora/Fapesp, 2005.

GARCIA, Nelson Jahr. Estado Novo - Ideologia e propaganda política. São Paulo: Loyola, 1982.

GEORGE OLIVEN, Ruben. “O Nacional e o Regional na Construção da Identidade Brasileira". Revista Brasileira de Ciências Sociais. Vol. 2, Anpocs. Disponível em http://www.anpocs.org.br/portal/publicacoes/rbcs_00_02/rb cs02_07.htm, acesso em 21/08/2013.

. O que é propaganda ideológica. São Paulo: Brasiliense, 1994. (Coleção primeiros passos) 
GOMES, Ângela de Castro. A invenção do trabalhismo. Rio de Janeiro: IUPERJ; São Paulo: Vértice, 1988.

HALL, Stuart. Identidades Culturais na Pós-modernidade. Rio de Janeiro: DP\&A, 1997.

HALL, Stuart. "Quem precisa da identidade?”. In: SILVA, Tomaz Tadeu da (org.). Identidade e diferença: a perspectiva dos estudos culturais. 6ª ed., Petrópolis: Vozes, 2006.

LAUERHASS, Ludwig Jr. Getúlio Vargas e o triunfo do nacionalismo brasileiro. São Paulo: Itatiaia/Edusp,1986.

MATOS, Claudia. Acertei no milhar: samba e malandragem no tempo de Getúlio. Rio de Janeiro: Paz Terra, 1982.

NAPOLITANO, Marcos. A síncope das idéias. A questão da tradição na música popular brasileira. São Paulo: Editora Fundação Perseu Abramo, 2007.

. Cultura Brasileira: utopia e massificação (1950/1980). $2^{\mathrm{a}}$ ed. São Paulo: Contexto, 2004.

. História \& música. Belo Horizonte: Autêntica, 2002.

OLIVEIRA, Lúcia Lippi; VELLOSO, Mônica Pimenta; GOMES, Ângela Maria de Castro. Estado Novo: ideologia poder. Rio Janeiro: Zahar Ed., 1982.

ORLANDI, Eni Pulccinelli. Análise de Discurso. Princípios e procedimentos. Campinas/São Paulo: Pontes, 1999. 
PARANHOS, Adalberto. "Entre sambas e bambas: vozes destoantes no 'Estado Novo'”. Locus. (Juiz de Fora), v. 13, 2007, p. 179192.

. O Roubo da fala. Origens do trabalhismo no Brasil. São Paulo. Boitempo Editorial, 1999.

. Os desafinados. Sambas e bambas no "Estado Novo". Tese (Doutoramento em História), PUC- SP, 2005.

. O Brasil dá samba? Os sambistas e a invenção do samba como 'coisa nossa'. Disponível em http://www.sambachoro.com.br/debates/1055709497, acesso em 21/08/2013.

. "Sons de sins e de nãos : a linguagem musical e a produção de sentidos”. Proj. História, São Paulo, n. 20, abr./2000.

. "A invenção do Brasil como terra do samba: os sambistas e sua afirmação social”. História (São Paulo), São Paulo-SP, v. 22, n. 1, 2003.

. "O coro da unanimidade nacional: o culto ao 'Estado Novo'". Revista de Sociologia e Política. Curitiba, v. 9, n. 9, 1997.

PEDRO, Antonio. O samba da legitimidade, Dissertação de mestrado, São Paulo, FFLCH/USP, 1980.

PEREIRA, Cristiane dos Santos. Coisas do meu Pessoal. Samba e enredos de raça e gênero na trajetória de Leci Brandão. 
Dissertação de Mestrado em História Cultural. Universidade de Brasília, 2010.

PESAVENTO, Sandra Jathay. História e História Cultural. Belo Horizonte: Editora Autêntica, 2003.

REVEL, Jacques. (org.). Jogos de escalas: a experiência da microanálise. Rio de Janeiro: Editora Fundação Getúlio Vargas, 1998.

SANDRONI, Carlos . Feitiço decente. Transformações do samba no Rio de Janeiro (1917-1933). Rio de Janeiro, Jorge Zahar / Editora UFRJ, 2001.

SAUTCHUK, João Miguel. Brasil, Ritmos e harmonias: samba e identidades na música popular brasileira (segunda metade do século XX/ tempo presente). Trabalho de conclusão de curso. (graduação em História) - Universidade de Brasília, 2003.

SILVA, Tomaz Tadeu da. "A produção social da identidade e da diferença”. _ _ (org.). Identidade e Diferença. A perspectiva dos Estudos Culturais. Petrópolis: Editora Vozes, 2000.

SODRÉ, Muniz. Samba, o dono do corpo. Rio de Janeiro: Codecri, 1979.

SQUEFF, Enio e WISNIK, José Miguel. Música - o nacional e o popular na cultura brasileira. São Paulo: Brasiliense, 1982. 
WOODWARD, Kathryn. "Identidade e diferença: uma introdução teórica e conceitual". In: SILVA, Tomaz Tadeu da (org.). Identidade e Diferença. A perspectiva dos Estudos Culturais. Petrópolis: Editora Vozes, 2000.

TINHORÃO, José Ramos. Pequena historia da música popular: Da modinha a canção de protesto. 2. ed. Petropolis: Editora Vozes Ltda, 1975.

XANGÔ. Xangố da Mangueira: recordações de um velho batuqueiro. Rio de Janeiro: Casa, 2005. 